УДК $378-047.22: 005.6$

(С) Друганова О.М., Білик В.М., 2019 р.

http://orcid.org./0000 - $0002-5985-8293$

http://orcid.org./0000 - 0002-1809-0804

DOI: $10.34142 / 23128046.2019 .47 .03$

О. М. Друганова, В. М. Білик

\title{
АКТУАЛЬНІСТЬ ПОГЛЯДІВ В. О. СУХОМЛИНСЬКОГО В УМОВАХ РОЗБУДОВИ НОВОЇ УКРАЇНСЬКОЇ ШКОЛИ
}

У статті аналізуються основні положення творчої спадщуини В. О. Сухомлинського щзодо організащії початкової школи, як основи підготовки нового покоління. В світлі реформування сучасної школи, поради видатного вченого стануть творчим орієнтиром для організації освітнього процесу у новій українській школі. Автори визначили найбільш актуальні для сьогодення поради науковия: організачія начального прочуесу в початковій школі, спрямована на розвиток допитливості, творчості, мислення маленької дитини; створення позитивної атмосфери; застосування дослідницького підходу в роботі дітей; уважне ставлення вчителя до кожного учня. У статті проаналізовано зв'язок ідей В. О. Сухомлинського з концеептуальними напрямами нової української школи: входження $i$ адаптація дитини в шкільному житті, створення ситуації успіху в навчанні, виховання відповідальності, творчого мислення. На основі аналізу сучасних освітніх документів, відгуків учителів, батьків, науковців та вагомих праць В. О. Сухомлинського автори довели, щуо індивідуальні особливості дитини були пріоритетними в творчій спадщуині видатного педагога і залишилися такими в українській школі нового типу. Проведене дослідження підтверджує актуальність поглядів відомого науковия для розбудови навчального процесу початкової школи Украӥни, формування нового вчителя та бачення розвиненої особистості учня.

Ключові слова: нова украӥнська икола, В.О. Сухомлинський, реформування, актуальність поглядів.

Druhanova O. M., Bilyk V. M. The relevance of V. O. Sukhomlinsky's views in the conditions of building a new Ukrainian school. Sukhomlinsky's main principles of creative heritage concerning organization of elementary school as a basis for the preparation of a new generation are analyzed in the article. In the light of reforming the present-day school, the prominent scholar's advice will become a creative benchmark for organizing the educational process in the new Ukrainian school. The authors identified the scientist's most relevant advice for the present: the organization of the initial process in elementary school aimed at developing child's curiosity, creativity and thinking; creating a positive atmosphere; the application of a research approach in children's work; attentive 
teacher's attitude to each student. The article shows the connection of V.O. Sukhomlinsky's ideas with the conceptual directions of the new Ukrainian school: entering and adapting a child in school life, creating a situation of success in learning, fostering responsibility, creative thinking. Based on the analysis of modern educational documents, teachers', parents' and scholars' responses and significant V. Sukhomlinsky's works, the authors proved that the individual characteristics of the child were a priority in the creative heritage of an outstanding teacher, and remained so in the Ukrainian school of a new type. The scientific search revealed the peculiarities of V. Sukhomlinsky's view that the child is always a thinker, and whether she is proud of the consequences of her activity depends on her perception of herself and the world around her. The study confirms the relevance of the views of a well-known scientist for the development of the educational process of elementary school in Ukraine, the formation of a new teacher and the vision of the developed personality of the student. The article draws attention to such important approaches to human formation as selfmastering of knowledge, development of skills and abilities, awareness of oneself in public life. It is these views that are inherent to the educators of the past and are the basis of modern science.

Keywords: new Ukrainian school, V.O. Sukhomlinskyi, reforming, relevance of views.

Вступ. Необхідність формування людини з новим типом мислення, новою свідомістю, розумінням свого місця в суспільстві, у житті; швидке оновлення інформації, збільшення іiі обсягу, що потребує від сучасного покоління вміння самостійно опановувати знання упродовж усього життя; втрата вчителем позиції єдиного джерела знань; відхід від традиційної педагогіки, що побудована за схемою «вчитель - підручник - учень» - усі ці та інші чинники доводять, що реформа, ініційована Міністерством освіти та науки України, є на часі.

Провідною ідеєю освітньої реформи стала Концепція Нової української школи, що була розроблена й презентована у процесі визначення стратегії розвитку освіти на період 2015 - 2025 рр. Важливо, що запропоновані зміни в освітній галузі були апробовані упродовж року у 100 пілотних школах і 3 минулого 2018/2019 навчального року впроваджені на всій території України.

Відповідно положень прийнятого документу, в початковій школі України передбачено два навчальних цикли: I - адаптаційно-ігровий (1-2 класи), метою якого є поступове занурення дитини в шкільну атмосферу, послідовна адаптація до нового соціуму; II - базовий (3 - 4 класи) цикл передбачає здійснення навчального процесу при підвищеній увазі педагога на формуванні у дітей самостійності і відповідального ставлення; підготовку до переходу в основну школу і успішне перебування в ній (2016). Нова 
українська школа, як наголошується на урядовому порталі, - це заклад, який хочеться відвідувати учням: у ній прислуховуються до дітей, вчать думати креативно, не боятись висловлювати власний погляд та відповідати за вчинки. Батькам теж до вподоби така школа, адже тут панують розуміння i співробітництво.

Зазначимо, що зміни, що були упроваджені у початкову школу стали об'єктом уваги не тільки з боку офіційних осіб - керівників Міністерства освіти i науки, регіональних чиновників від освіти тощо, а й широкої наукової та педагогічної громадськості, безпосередніх учасників освітнього процесу - вчителів, батьків, учнів. Адже мета сучасної школи - навчити молодь здобуті знання і навички застосовувати в житті.

Олексій Сімончук у статті «Без домашніх завдань і оцінок. Що таке Нова українська школа» у переліку змін, що відбуваються у початковій школі називає такі: у першому класі оцінок ставити не будуть; у 2-4 класах учні отримають оцінки лише з окремих дисциплін (українська мова і література, математика); дзвінків, що закликають на урок, не буде; інтегровані предмети об’єднуватимуть навколо тем, цікавих для дитини та ін. Дописувач зазначає, що більша частина навчальних занять проходитиме у формі гри, що сприяє концентрації уваги i пам'яті дітей. Основний акцент робиться на індивідуальні особливості й задатки дитини (Simonchuk, 2017).

Експерт центру аналітики CEDOS Ірина Когут підкреслює, що в новій українській школі процес засвоєння знань стане більш зрозумілим для дітей. Цікаво, що теми для вивчення вчителі вибиратимуть разом з учнями. У процесі навчання вони зможуть виконувати завдання на основі знайомих i улюблених захоплень (мультфільмів, казок, подій). Наприклад, скласти листа герою мультфільму або обчислити кількість годин його подорожей тощо. Дітям набагато цікавіше пізнавати світ з улюбленими сюжетами, ніж вивчати істини, сформульовані в підручниках (Simonchuk, 2017).

Установлено, що нова українська школа стала об'єктом уваги й широкої батьківської громади. У соціальних мережах утворилися цілі об’єднання батьків, діти яких почали навчатися в минулому, чи позаминулому роках у новій початковій школі. Відгуки й думки батьків різняться як за оцінкою змісту навчання, так і самої організації навчального процесу.

Наслідки реформування в освітній галузі, зрозуміло, зможемо оцінити лише через 10-11 років, лише після того, як відбудеться випуск тих дітей, що прийшли до нової української школи у минулому та позаминулому роках. Проте, спираючись на дорогоцінну спадщину українського народу, що перевірена часом і самим життям, спробуємо окреслити виклики й ризики, 
що постали перед вчителями нової школи, від успішного розв'язання яких буде залежати ефективність реалізації освітньої реформи, ініційованої Міністерством.

Важливим інструментом перевірки й прогнозування наслідків запропонованих змін, як відомо, $є$ історико-педагогічні знання. У цьому плані важливого значення набувають науково-педагогічні ідеї й багаторічний досвід роботи із дітьми видатного українського педагога, справжнього гуманіста, «Песталоцці XXI століття», якого порівнюють із Ж. Ж. Руссо i пов’язують із Сократом - Василя Олександровича Сухомлинського.

Зауважимо, що спадщина видатного педагога багато років є предметом ретельного наукового аналізу як вітчизняних (Л. Березівська, А. Троцко, К. Юр'єва та ін.), так і зарубіжних учених. Особливої ваги вона набуває в сучасних умовах реформування освітньої галузі в Україні. Отже, саме педагогіку В. О. Сухомлинського свого часу було визначено як педагогіку гуманізму, дбайливого ставлення до маленької дитини.

Мета та завдання. На основі вивчення творчої спадщини В. О. Сухомлинського висвітлити основні положення щодо організації початкової школи як основи підготовки нового покоління, які стануть творчим орієнтиром для організації освітнього процесу в новій українській школі.

Методи дослідження. У процесі написання статті використано загальнонаукові методи (аналіз, синтез, узагальнення тощо), що дозволило 3’ясувати актуальність порушеної проблеми, ступінь іiі обговорення у суспільстві, визначити сутність, складники й особливості педагогічної роботи В. О. Сухомлинського з дітьми молодшого шкільного віку; розкрити перспективи творчого використання набутих ідей для сучасної педагогічної громадськості.

Результати. Видатний вітчизняний педагог XIX ст. К. Д. Ушинський, визначаючи роль праці в психічному й виховному значенні, зазначав, що розумова праця чи не найважча праця для людини. «Мріяти легко i приємно, а мислити - важко. Не тільки в дітей, а й у дорослих ми найчастіше спостерігаємо лінощі думки. Хлопець ладен швидше попрацювати фізично увесь день або просидіти без думки над однією й тією ж сторінкою кілька годин і визубрити іi механічно, ніж подумати серйозно кілька хвилин. Крім того, серйозна розумова праця стомлює незвиклу людину швидше, ніж найважча фізична праця», - наголошував К. Д. Ушинський у роботі «Праця в пї психічному і виховному значенні» (Ushynskyi, 1983). Висновок, який він зробив - виховання не тільки повинно розвинути розум людини й дати їй певний обсяг відомостей, але повинно 
запалити в ній жадобу серйозної праці, без якої життя іï не може бути ні гідним, ні щасливим.

Варто зазначити, що думки видатного мислителя К. Д. Ушинського знайшли продовження в спадщині українського гуманіста XX століття Василя Олександровича Сухомлинського. На сторінках всесвітньовідомого твору «Серце віддаю дітям» В. О. Сухомлинський неодноразово звертається до творчого спадку К. Д. Ушинського, підтверджуючи свої погляди, перевіряючи власні переконання, розвиваючи висунуті положення 3 урахуванням досягнень сучасних психологів, педагогів та інших науковців. Так, аналіз педагогічного доробку вітчизняного «Песталоцці» свідчить, що велику увагу у формуванні особистості він надавав саме початковій школі, яка закладає фундамент розвитку людини.

Наголосимо, що педагогічний колектив Павлиської школи на чолі 3 В. О. Сухомлинським ставили перед собою мету - досягти, щоб у школі не було байдужих учнів, яким не цікаво вчити вірші або запам'ятовувати математичні формули, яких ніщо не хвилює, не захоплює. В. О. Сухомлинський разом із іншими вчителями, прагнув, щоб кожний вихованець із самого першого кроку в школі мав захоплення, щось полюбив, що допоможе розкрити i розвинути творчі здібності, визначити життєве покликання дитини (Sukhomlynskyi, 1977). Видатний педагог попереджав, що лінивими діти стають у самій школі тому, що їх із молодших класів не навчили любити шкільну працю і не дали їм відчути радість успіху в навчанні.

Адже дитяче бажання добре вчитися, як зауважував просвітник, не є такою якістю, що залежить від якихось природних особливостей дитини, а виховується в повсякденній праці, в подоланні труднощів (Sukhomlynskyi, 1977). Там, де відсутнє радісне захоплення працею навчання, немає бентежного подиву від відкриття істини завдяки напруженню внутрішніх сил дитячої душі, не йде мова про любов до науки, до знань, - робить висновок В. О. Сухомлинський у статті «Вчити вчитися» (Sukhomlynskyi, 1977).

Наголосимо, що видатний гуманіст називав бажання вчитися «дуже тонкою і примхливою річчю», «ніжною квіткою», котра живиться від тисячі корінців, що невтомно працюють лише у вологому грунті. Ми не бачимо їх, але оберігаємо, дбаємо, розуміючи, що життя і краса без них загинуть, писав освітянин (Sukhomlynskyi, 1977).

Шлях реалізації поставленого завдання - палко зацікавити кожну дитину в навчанні - просвітник убачав у створенні багатого, різноманітного, приваблюючого інтелектуального життя. На слушну думку В. О. Сухомлинського, «знання набувають роль фактору, що визначає 
готовність людини до життя тільки тоді, коли ці знання здобуті активними розумовими зусиллями, поєднанням роботи рук i творчості думки» (Sukhomlynskyi, 1977). Водночас мислитель зауважував, що необхідно постійно піклуватись, щоб $з$ приходом до школи думка дитини не була обмежена рамками класної дошки, сторінками букваря: щоб стіни класу не затуляли різноманітність світу, в таємницях якого - невичерпні джерела творчості. Іншими словами: щоб дитина хотіла вчитися, іiі інтелектуальне життя ні в якому разі не може обмежуватися лише учнівськими підходами, які спрямовані на запам’ятовування, заучування та подальше відтворювання знань для перевірки учителем.

Утім, В. О. Сухомлинський попереджав, що нехай у читачів не складається враження, ніби він зневажливо ставиться до запам'ятовування та заучування. Без виконання цих функцій, за глибоким переконанням педагога, навчання i розумовий розвиток були б ускладнені. Але, якщо навчання перетворюється тільки в роботу пам'яті, підкреслював В. О. Сухомлинський, воно стає безпредметним, безцільним. Справжній розумовий розвиток можливий лише за умов поєднання зусиль пам'яті й думки, осмислення явищ, закономірностей навколишнього світу ((Sukhomlynskyi, 1977).

Установлено, що важливе місце у роботі з дітьми, що прийшли до школи, В. О. Сухомлинський надавав, передусім, урокам мислення, або «подорожі до першоджерел думки». Такі уроки, що проводилися 3 дітьми в садку i в лісі, в полі i на березі ставка; відкривали перед ними найрізноманітніші відтінки і грані предметів, явищ, відношень, залежностей. Система уроків мислення - це школа думки, без якої, як писав педагог, вони не уявляли повної, ефективної розумової праці не лише в початкових класах, а й у наступні періоди шкільного навчання. Ця школа, на його переконання, $є$ фундаментом творчих інтелектуальних сил, необхідних для здобуття нових знань.

На думку вчителів-початківців нашої школи, - зазначав гуманіст, виховне значення уроків мислення полягає передусім у невпинному застосуванні знань. Виховати прагнення до навчання можливо лише за умов, коли дитина опановує в початковій школі знання не як мертвий скарб, що нагромаджується в дитячій голові для того, щоб учитель мав можливість виймати їх 3 «комори» для перевірки. Розвинені розумові здібності - це рухливі знання, які завжди можна застосувати (Sukhomlynskyi, 1977).

Завдяки такому підходу школяр стає трудівником думки. Уроки мислення - не універсальний засіб пробудження розумових задатків i виховання бажання у дітей вчитися. Та, мабуть, це найдоцільніший засіб формування поглядів вихованців, їх ставлення до інтелектуальної праці й до 
самих себе. Найголовніше, що вже в молодшому віці дитина усвідомлює вона мисляча особистість. Переживання, завдяки власному досвіду привабливості застосування знань, відчуття гордості за володіння ними, веде маленьку людину до поступового перенесення свого ставлення до оточуючого світу на себе, на книжку. «Читати природу ми вчимо дітей для того, щоб навчити їх читати книжку» (Sukhomlynskyi, 1977).

Отже, другою ланкою в ланцюзі процесу навчити дитину вчитися в Павлиській школі стало залучення дитини до процесу читання, важливим завданням якого $є$ «виховати школяра допитливим, вдумливим читачем» (Sukhomlynskyi, 1977). «Думки, пробуджені над книжкою, як зауважував В. О. Сухомлинський, $є$ мовби добре обробленим полем, на яке падає насіння знань, проростає, дає врожай. Завдяки роздумам над книжкою полегшується засвоєння програмного матеріалу. Чим більше учень міркує над прочитаним, чим більше у нього почуття захоплення, пробуджене літературою, тим легше йому вчитися» (Sukhomlynskyi, 1977). Читати необхідно не тільки для того, щоб знайти якийсь засіб від марнотратства часу, а щоб жити в світі книжок. «Що та як читають діти, який слід лишає читання в духовному житті вихованця? Це питання великої ваги», - писав В. О. Сухомлинський (Sukhomlynskyi, 1977).

Особливе значення в створенні повноцінного бажання вчитися, на переконання знаного педагога, має творчість, яка, у свою чергу, $\epsilon$ «щаблинкою самостійного мислення, на якій дитина пізнає радість власної думки, переживає моральну гідність творця» (Sukhomlynskyi, 1977). Передусім, В. О. Сухомлинський великої уваги приділяв творчості засобами слова. Кожен учитель початкових класів Павлиської школи систематично проводив ранки дитячої творчості. Діти читали свої оповідання, вірші.

Актуальними для сьогодення стануть поради видатного гуманіста й щодо правильної організації педагогічного процесу в цілому й кожного уроку, зокрема. Просвітник застерігав, що «глибоко помиляються вчителі, які вважають, що, якщо вони більш зрозуміло, більш дохідливо подадуть матеріали, менше виникне запитань з боку дітей, то більш глибокими будуть знання учнів» (Sukhomlynskyi, 1977). Так, В. О. Сухомлинський наводить приклад, коли одна вчителька початкових класів вважалася майстром пояснення змісту арифметичних задач. Щоб умова задачі «дійшла» до учнів, вона заздалегідь готувала малюнки, графіки, іноді навіть приносила на уроки речі, про які йшлося у задачах. Ї̈̈ учні нібито чудово розв'язували задачі. Але коли вони прийшли в 5 клас, педагогічний колектив був здивований: вихованці цієї вчительки зовсім не вміли розв'язувати задачі. Це справді було так, тому що протягом 4 років вчителька дбайливо оберігала дітей від 
труднощів і вони, по суті, «не навчилися активно мислити» (Sukhomlynskyi, 1977).

Український педагог був переконаний, що для того, щоб діти хотіли вчитися, зовсім не обов'язково робити кожен урок цікавим, не треба розважати дітей і придумувати щось незвичайне. Секрет бажання вчитися насамперед в успіхах дітей, в їхньому відчутті зростання, руху, осягнення складного. Досвідчені вчителі розуміють, як зазначав В. О. Сухомлинський, що детальне пояснення того чи іншого явища, події, закономірності повинно не тільки розкривати перед учнями суть матеріалу, а й учити їх мислити, самостійно приходити своїми силами до такого самого детального пояснення (Sukhomlynskyi, 1977). Узагалі перехід від конкретного чуттєвого уявлення до абстракції, понять, суджень, умовиводів, як зауважував педагог, - дуже важливий момент активізації розумової праці, особливо в початкових класах - у тому віці, коли відбувається інтенсивний перехід від мислення образного до мислення абстрактного, логічного (Sukhomlynskyi, 1977).

Установлено, що характерною особливістю роботи учнів у кращих педагогів, за спостереженнями В. О. Сухомлинського, був дослідницький підхід до предмета вивчення. Педагоги не давали учневі готових висновків, доведень правильності тієї чи іншої істини, а створювали для школяра можливість висунути кілька пояснень, у самій дійсності знайти підтвердження й спростування кожної з висунутих гіпотез. Вихованці, при такій організації уроку, доводять одне і спростовують інше - як практикою у вузькому розумінні цього слова, тобто безпосередніми спостереженнями над фактами і явищами, так і опосередкованим мисленням. Знання при цьому, як зазначав В. О. Сухомлинський, не пасивно засвоюються, як звикли говорити вчителі, а здобуваються активними зусиллями. Тому такі знання стають переконаннями, і учні цінують їх (Sukhomlynskyi, 1977).

Можливості для застосування дослідницького підходу, як слушно зауважував видатний гуманіст, можна знайти вчителям і гуманітарних, i природничих предметів, і під час вивчення основ наук про суспільство, особливо історії і літератури, у самому матеріалі, який необхідно вчити. Знання набуті в процесі вдумливого аналізу фактів, порівнянь і зіставлень, свідомого прагнення подолати труднощі, як підкреслював Василь Олександрович, зберігаються в пам'яті значно міцніше, глибше, i, що дуже важливо, учні намагаються повніше використати їх надалі в своїй практиці (Sukhomlynskyi, 1977).

Завдання вчителя при такій організації навчального процесу полягає в тому, щоб учням стала ясною суть зрозумілого й незрозумілого, щоб саме 
запитання не давало спокою, а можливість відповісти на нього поставала як можливість захоплюючої, цікавої праці (Sukhomlynskyi, 1977).

Варто зауважити, що суттєву увагу приділяв В. О. Сухомлинський i вадам, які спостерігалися у роботі вчителів. Так, «великою хибою» в організації та проведенні уроку просвітник вважав «байдужість», «безпристрасне ставлення» вчителя до знань учнів. Коли вчитель однаково ставить i «5», i «3», i «2», тоді відмінні оцінки сприймаються учнями не як результат наполегливої праці, а як справа випадку; незадовільні оцінки сприймаються як невдача, що спіткала учня, як результат того, що випало «важке запитання», - зазначав В. О. Сухомлинський (Sukhomlynskyi, 1977). Педагог стверджував, що така безпристрасність у роботі самого вчителя стає причиною байдужості учнів як до своїх успіхів у навчанні, так і до успіхів і невдач своїх товаришів.

Важливо, що таку байдужість В.О. Сухомлинський убачав і у прагненні вчителя спростити матеріал, позбавити його труднощів, важких для засвоєння місць. Коли вчитель, готуючись до уроку, не зосереджує увагу на найважчому, навіть більш того, він намагається гранично полегшити це «важке», створити враження, що в навчальному матеріалі немає нічого складного, що все можна засвоїти дуже легко, $є$, на переконання просвітника, «неправильним шляхом». Замість того, щоб учити дітей долати труднощі, учитель штучно полегшує засвоєння важкого навчального матеріалу, згладжуючи «гострі кути». Внаслідок цього в деяких випадках важливий навчальний матеріал, по суті, опускається або вивчається мимохідь (Sukhomlynskyi, 1977). Засуджував В. О. Сухомлинський і байдуже ставлення вчителя до навчального матеріалу, яке відразу ж передається учням.

Велике значення у вихованні стійкого бажання вчитися й досягати щоразу кращих успіхів, на глибоке переконання видатного вітчизняного педагога, має й бадьорий, життєрадісний тон, який створюється на уроці вчителем (Sukhomlynskyi, 1977). Прагнення до знань, як зазначав В. О. Сухомлинський, живиться тисячами «невсипущих, невтомних коренів» важкої, але цікавої, жаданої для дитини праці. А такою вона стає за умов напруження сил, які є невіддільними від усвідомлення власної гідності. Дитина повинна відчувати себе трудівником, пишатися наслідками своєї праці. Виробити гордість - значить створити в душі бажання бути мислителем. Це одна 3 найтонших сфер усієї педагогіки. «Немає відчуття гідності, пробудженої розумовою працею, немає й виховання в процесі навчання, не може й бути мови про єдність навчання й виховання», - слушно наголошував педагог (Sukhomlynskyi, 1977). 
Обговорення. Проведений науковий пошук дозволяє стверджувати, що в умовах розбудови нової української школи великої ваги набуває звернення видатного українського педагога до педагогів: «Дбаймо, шановні колеги, щоб дитина в початковій школі була передусім думаючою, активним здобувачем знань, допитливим шукачем істини, мандрівником у світі пізнання. Лише в такому разі вона буде добрим школярем» (Sukhomlynskyi, 1977).

Висновки. Таким чином, творча спадщина Василя Олександровича Сухомлинського не втратила своєї актуальності й може стати справжньою школою педагогічної майстерності вчителів нової української школи, допомагаючи їм успішно подолати усі виклики й загрози, а також сформулювати своє власне педагогічне кредо.

\section{ЛІТЕРАТУРА:}

Нова українська школа. Концептуальні засади реформування середньої школи. Режим доступу: https://mon.gov.ua/storage/app/media/zagalna\%20serednya/nova-ukrainskashkola-compressed.pdf

Сімончук О. Без домашніх завдань і оцінок. Що таке Нова українська школа. Режим доступу: https:/osvitoria.media/experience/bez-domashnih-zavdan-i-otsinok/

Сухомлинський В. О. Вчити вчитися. Вибрані педагогічні твори: в 5 m. Т. 5. К. : Радянська школа, 1977. 637 с.

Сухомлинський В. О. Інтерес до учня - важливий стимул навчальної діяльності учнів. Вибрані педагогічні твори: в 5 m. Т. 5. К. : Радянська школа,1977. 637 с.

Сухомлинський В. О. Розумова праця і зв'язок школи з життям. Вибрані педагогічні твори: в 5 m. Т. 5. К. : Радянська школа, 1977. 637 с.

Сухомлинський В. О. Розвиток індивідуальних здібностей і нахилів учнів. Вибрані педагогічні твори: в 5 m. Т. 5. К. : Радянська школа, 1977. 637 с.

Ушинський К. Д. Праця в її психічному і виховному значенні. Вибрані педагогічні твори: в 2 m. Т. 1. К. : Радянська школа, 1983. С.43.

\section{REFERENCES:}

Nova ukrainska shkola. Kontseptualni zasady reformuvannia serednoi shkoly. (2016) [New Ukrainian School. Conceptual principles of secondary school reform]. Retrieved from https://mon.gov.ua/storage/app/media/zagalna\%20serednya/nova-ukrainska-shkolacompressed.pdf (in Ukranian).

Simonchuk, O. (2017) Bez domashnikh zavdan i otsinok. Shcho take Nova ukrainska shkola. [No homework and grades. What is New Ukrainian School]. Retrieved from https://osvitoria.media/experience/bez-domashnih-zavdan-i-otsinok/ (in Ukranian).

Sukhomlynskyi, V. O. (1977). Vchyty vchytysia. [Learning to learn]. Vybrani pedahohichni tvory: $v 5$ t. T. 5. Kyiv: Radianska shkola (in Ukranian).

Sukhomlynskyi, V. O. (1977). Interes do uchnia - vazhlyvyi stymul navchalnoi diialnosti uchniv. [Interest in the student is an important impetus for students' learning activities]. Vybrani pedahohichni tvory: $v 5$ t. T. 5. Kyiv: Radianska shkola (in Ukranian).

Sukhomlynskyi, V. O. (1977). Rozumova pratsia i zv'iazok shkoly z zhyttiam. [Mind work and the connection of school to life]. Vybrani pedahohichni tvory: $v 5 t$. T. 5 . Kyiv: Radianska shkola (in Ukranian). 
Sukhomlynskyi, V.O. (1977). Rozvytok indyvidualnykh zdibnostei i nakhyliv uchniv. [Development of students' individual abilities and inclinations]. Vybrani pedahohichni tvory: $v 5$ t. T. 5 . Kyiv: Radianska shkola (in Ukranian).

Ushynskyi, K. D. (1983). Pratsia v yii psykhichnomu i vykhovnomu znachenni. [Work in its mental and educational value]. Vybrani pedahohichni tvory: $v 2$ t. T. 1. Kyiv: Radianska shkola (in Ukranian).

\section{Інформація про авторів:}

Друганова Олена Миколаївна:

ORCID: http://orcid.org./0000 - $0002-5985$ - 8293, доктор педагогічних наук, професор, професор кафедри історії педагогіки i порівняльної педагогіки Харківського національного педагогічного університету імені Г.С. Сковороди, вул. Валентинівська, 2, м. Харків, Україна, 611666

e-mail: druganova_lena@ukr.net.

\section{Білик Вікторія Миколаївна:}

ORCID: http://orcid.org./0000 - $0002-1809$ - 0804, кандидат педагогічних наук, доцент, доцент кафедри педагогіки i порівняльної педагогіки Харківського національного педагогічного університету імені Г.С. Сковороди, вул. Валентинівська, 2, м. Харків, Україна, 611666.

\section{Information about the authors:} Druhanova Olena Mykolaivna:

ORCID: http://orcid.org./0000 - $0002-5985$ - 8293, Dr. hab. in Pedagogy, Professor, Professor of History of Pedagogy and Comparative Pedagogy Department, H. S. Skovoroda Kharkiv National Pedagogical University, Valentynivska street, 2, Kharkiv, Ukraine, 61666.

e-mail: druganova_lena@ukr.net

\section{Bilyk Viktoriia Mykolaivna:}

ORCID: http://orcid.org./0000 - $0002-1809$ - 0804, PhD in Pedagogy, Associate Professor of History of Pedagogy and Comparative Pedagogy Department, H. S. Skovoroda Kharkiv National Pedagogical University, Valentynivska street, 2, Kharkiv, Ukraine, 61666.

e-mail: bilykvita@ukr.net

e-mail: bilykvita@ukr.net

Цитуйте цю статтю як: Друганова О.М., Білик В.М. Актуальність поглядів B.О. Сухомлинського в умовах розбудови нової української школи. Теорія та методика навчання та виховання. 2019. № 47. С.26-36.

DOI: $10.34142 / 23128046.2019 .47 .03$

Дата надходження статті до редакції: 12.11.2019

Стаття прийнята до друку: 26.11.2019 